\title{
Ortaokul 6. Sınıf İngilizce Ders Kitaplarında Yer Verilen Değerler
}

\author{
Halil İbrahim Aslan ${ }^{1 *}$ \\ Doç. Dr. Sevgi Coşkun Keskin ${ }^{2}$ \\ Uzm. Selçuk Önder ${ }^{3}$
}

Geliş tarihi: 10.04 .2019

Kabul tarihi: 07.05.2019

\section{Atıf bilgisi: \\ Uluslararası Bilimsel Araștırmalar Dergisi (IBAD) \\ Cilt: $4 \quad$ Sayı: 2 \\ Sayfa: 355-371 Yll: 2019 \\ Dönem: Yaz}

This article was checked by iThenticate. Similarity Index 14\%

\footnotetext{
1 Sakarya Üniversitesi, Türkiye, aslanhalilibrahim@gmail.com ORCID ID 0000-0002-1004-0538

2 Sakarya Üniversitesi, Türkiye, scoskun@sakarya.edu.tr ORCID ID 0000-0001-2345-6789

3 Sakarya Üniversitesi, Türkiye, selcukonder@hotmail.com ORCID ID 0000-0002-4976-3178
}

ÖZ

Türkiye'de bazı dünya ülkelerinde olduğu gibi İngilizce ikinci dil olarak öğretilmektedir. Şüphesiz dil öğretiminde öğretilen dilin kültürel unsurları ve değerleri, dil öğretiminin bir parçasıdır. Değerlerin aktarımı konusu da dil en önemli öğelerden biridir. Ders kitapları öğretimin en önemli araçlarındandır. Bu bağlamdan hareketle tarama modeli kullanılarak çalışmada; 2018 y1lına ait İngilizce dersi öğretimin programına dayalı olarak yazılan, ortaokul altıncı sınıflarda MEB tarafindan okutulması uygun görülen İngilizce ders kitabı, üniteler bazında incelenerek hangi değerlere yer verildiği incelenmiştir. Milli Eğitim Bakanlığının tüm dersler için tavsiye ettiği değerler kullanılarak hazırlanan bir form üzerinde toplam 10 ünite analiz edilmiştir. Dokuman analizi tekniği kullanılarak yapılan analiz sonucunda sağlıklı olmaya önem verme, demokrasi bilincine önem verme, doğa sevgisi gibi değerlere odaklanılırken, Milli eğitim Bakanlığının İngilizce dersi öğretim programında ön gördüğ̈̈ değerlerden adil olma, dürüstlük, sabır, vatanseverlik, öz denetim ve diğerkâmlığa ilișkin herhangi bir veriye rastlanmamıştır.

Anahtar Kelimeler: Değerler eğitimi, İngilizce dersi, ders kitabı 


\title{
Values in the 6th Grade English Textbooks
}

\author{
Halil İbrahim Aslan ${ }^{1 *}$ \\ Doç. Dr. Sevgi Coşkun Keskin ${ }^{2}$ \\ Uzm. Selçuk Önder ${ }^{3}$
}

First received: 10.04 .2019

Accepted: 07.05.2019

\section{Citation:}

Journal of the International

Scientific Research (IBAD)

Volume: 4 Issue: 2

Pages: 355-371 Year: 2019

Session: Summer

This article was checked by iThenticate. Similarity Index 14\%

\begin{abstract}
In Turkey, English is taught as a second language as in some other countries. Undoubtedly, the cultural elements and values of the language taught in language teaching are important parts of language teaching. Values education is one of the most important elements of the language. In this context, by using the scanning model in the study, The English course book, which was written based on the program of English language teaching in 2018, and which was approved by the Ministry of National Education in the sixth grades of secondary schools, was examined on the basis of units to find out which values were included. A total of 10 units were analyzed on a form prepared using the values recommended by the Ministry of National Education for all subjects. The analysis which was done through document analysis technique showed that while there were a lot of focus on the values such as responsibility, importance of being healthy, giving importance to democracy, there were no data about fairness, honesty, patience, patriotism, self-control and altruism from the values planned by the Ministry of National Education in the English curriculum.
\end{abstract}

Keywords: Values education, English lesson, course book

\footnotetext{
1 Sakarya University, Turkey, aslanhalilibrahim@gmail.com ORCID ID 0000-0002-1004-0538

2 Sakarya University, Turkey, scoskun@sakarya.edu.tr ORCID ID 0000-0001-2345-6789

3 Sakarya University, Turkey, selcukonder@hotmail.com

ORCID ID 0000-0002-4976-3178
}

* Corresponding Author 


\section{GİRIŞ}

Milli ve evrensel değerlerin sonraki nesle aktarımı, toplumların ayakta durması ve bireylerin topluma uyum sağlayıp sağlıklı ve huzurlu bir yaşam sürmesi açısından elzemdir. Şüphesiz bireylerin değerler edinimi süreci ailede başlamaktadır. Bununla birlikte değerlerin şekillenmesinde okul ve sosyal çevre de önemli bir etkiye sahiptir. Zira bireyler, değerlerini aile ortamında, okullarda ve sosyal çevrelerinde edinirler. Aynı zamanda edindikleri bu değerleri yansıtarak tutum ve davranış haline getirme imkânı bulurlar (Aydın, 2008; Aydın ve Gürler, 2014).

Günümüzde değer edinme sürecinde okulun rolü çok daha önemli hale gelmiştir. Geçmişte her ne kadar okulun değer kazandırma sürecinde tarafsız olması gerektiğine dair tartışmalar yaşanmış olsa da 21. yüzyıl toplumlarında değerlerin yozlaşması veya kaybolması, okulların değer edinme sürecinde aktif rol oynaması gerektiğini çoğunluğun kabul etmesi şeklinde tezahür etmiştir (Lickona, 1991).

Okullarda öğrenciler, öğretmenlerini, arkadaşlarını ve okulda sunulan ortamı model alarak, kasıtlı veya kasıtsız şekilde değer edinebilirler. Bu nedenle öğrenciye sunulan okul ortamı, değerlerin doğru şekilde kazandırılmasında önemli bir yer tutar. Bununla birlikte okullarda, öğrenciye kazandırılmak istenen milli ve evrensel değerlerin, belirli bir müfredat ve program dahilinde tüm derslerde öğrenciye aktarılması ve bu doğrultuda tutum ve davranış geliştirmesi hedeflenmektedir (Çengelci, Hanc1 ve Karaduman, 2013). Oluşturulan müfredat ve programlarda, değer öğretiminin doğrudan veya dolaylı olarak yapılmasını öngören yaklaşımlar mevcuttur. Bunlardan bazıları; değerlerin telkin edilmesi, değer açıklama, değer analizi, ahlaki muhakeme, örtük program yoluyla öğretim, eylem öğrenme, karakter eğitimi gibi yaklaşımlardır (Önder, 2018). Farklı yaklaşım ve tekniklerin derslerde ve ders dışı etkinliklerde, gerekli ortam ve materyaller sağlanarak kullanılması, okullarda değer öğretiminin temelini oluşturmaktadır. Türkiye'de son yıllarda oluşturulan ders müfredatlarında belirlenen kazanımlar incelendiğinde, değer ediniminin odak nokta haline geldiği söylenebilir. TTKB'nin özel eğitim, ilkokul, ortaokul, ortaöğretim, mesleki ve teknik eğitim bazında yayımladığ kazanımları kendini göstermektedir (MEB, 2019).

Öğretim programlarına göre en çok kullanılan ders materyalleri ders kitaplarıdır. "Ders kitapları, öğretim programlarında yer alan konulara ait bilgileri planlı ve düzenli bir biçimde inceleyip açıklayan, bilgi kaynağı olarak öğrenciyi dersin hedefleri doğrultusunda yönlendiren ve eğiten temel bir ortamdır. Ders kitapları, öğretim sürecinin vazgeçilmez araçları olan tamamlayıcı öğretim materyalleridir" (Ünsal ve Güneş, 2002). Ders kitaplarında yer alan bilgi ve görsel açık ya da örtük bir şekilde değer eğitimini de içine alabilir. Öte yandan yabancı dil öğretiminde de açık ya da örtük bir şekilde değer eğitimi yapılmaktadır. Zira dil, ait olduğu toplumun düşünce biçimini yansıtan bir araçtır. Dil, toplumla birlikte geliştiği için yabancı bir dile hakim olabilmenin ilk şartı o toplum gibi düşünebilmektir (Er, 2006). Bu nedenle dil öğretimi yapılırken değerler de birlikte aktarılmaktadır.

Milli Eğitim Bakanlığınca hazırlanan ders kitaplarındaki değer kazanımlarının incelenmesi açısından, gerçekleştirilen çalışmalara ilişkin alan yazın incelendiğinde hayat bilgisi, Türkçe, sosyal bilgiler, tarih, din kültürü ve ahlak bilgisi gibi dersler ön plana çıkmaktadır (Candan ve Ergen, 2014; Çekin, 2012; Demircioğlu ve Tokdemir, 2008; Doğan ve Gülüşen, 2011; Kaygana, Yapıcı ve Aytan, 2013; Keskin, 2008; Somuncu, 2008; Şimşek, 2013). Diğer taraftan yabancı dil ders müfredatı ve ders kitaplarının değer öğretimi ve kazanımı açısından incelendiği herhangi bir çalışmaya rastlanmamıştır.

Değerlerin aktarımı konusunda dil en önemli öğelerden biridir. Bireylerin ana dili değer kazanımında ve aktarımında temel faktördür ve anlamanın, düşünmenin, iletişim kurmanın, sosyalleşmenin kaynağıdır. Bununla birlikte yabancı dil dersleri hem milli ve evrensel değerleri kazandırmada hem de farklı kültürlerdeki değerleri tanıtmada etkin bir araç olarak kullanılabilir. $\mathrm{Bu}$ bağlamda, yapılan bu çalışmada 2018 yılına ait İngilizce dersi öğretimin programına dayalı olarak yazılan ortaokul altıncı sınıflarda MEB tarafından okutulması uygun görülen İngilizce ders kitabı, üniteler bazında incelenerek hangi değerlere ne şekilde yer verildiği irdelenmiştir.

\section{YÖNTEM}

Araştırma deseni. Çalışma, tarama model bağlamında doküman analizi tekniği kullanılarak yapılmıştır. Bilindiği üzere tarama modelleri, geçmişte ya da hali hazırda olan bir durumu kendi şartları içinde 
olduğu gibi tanımlamayı amaçlamaktadır (Eroğlu ve Köktan, 2008). Bu araştırmada da 2018 tarihli, Ortaokul İngilizce Dersi Öğretim Programına dayalı olarak hazırlanmış 6. sınıf ders kitabının yer verdiği değerlerin incelenmesi amaçlanmıştır. Bu nedenle doküman incelemesi yapılmıştır. Zira doküman incelemesi, araştırılması hedeflenen olgu veya olgular hakkında bilgi içeren yazılı materyallerin analizini kapsamaktadır (Yıldırım ve Şimşek, 2011).

Örneklem. Doküman incelemesiyle yapılan araştırmalarda, tüm doküman verisinin bir bütün olarak analize konu olması mümkün olmayabilir. Bu nedenle, eldeki veri setinin içinden bir örneklem oluşturulabilir (Yıldırım ve Şimşek, 2011). Buradan hareketle çalışmada kolay ulaşılabilir durum örneklemesi kullanılmış ve 2018 tarihli Ortaokul İngilizce Dersi Öğretim Programına dayalı olarak hazırlanmış 6. sınıf düzeyinde hali hazırda ortaokullarda okutulan "Ortaokul ve İmama Hatip Ortaokulu İngilizce 6 Ders Kitabı” (Demircan, Akıskalı, Berket ve Günay, 2018) incelenmiştir. Bu kitaptaki 179 sayfada yer alan, 10 ünite (Yaşam (Life), Lezzetli Kahvaltı (Yummy Breakfast), Şehir Merkezi (Downtown), Hava ve Duygular (Weather And Emotions), Lunaparkta (At The Fair), Meslekler (Occupations), Tatiller (Vacations), Kitap Kurtlan (Bookworms), Gezegeni Kurtarmak (Saving the Planet) ve Demokrasi (Democracy) araştırma amacı doğrultusunda incelenmiştir.

Veri Toplama Süreci ve Analizi. Bilindiği üzere çoğu zaman tarama modelleri betimsel analiz süreçlerini içermektedir (Eroğlu ve Köktan, 2008). Bu nedenle çalışmada veri toplama ve analiz sürecinde betimsel analiz basamakları kullanılmıştır. Bu basamaklar şunlardır (Altunışık, Coşkun, Bayraktaroğlu ve Yıldırım, 2007, s.268):

- Betimsel analiz için bir çerçeve oluşturma

- Çerçeveye göre verilerin işlenmesi

- Bulguların tanımlanması

- Bulguların yorumlanmasi

Betimsel analiz için bir çerçeve oluşturma. Bu aşamada Milli Eğitim Bakanlığı Talim Terbiye Kuruluna ilk ve ortaokul düzeyindeki tüm ders programlarında yer alan ve literatürde öne çıkmış olan değerlerin listesi derlenmiş ve tablo haline getirilmiştir. Böylece kitabın analizinde kullanılacak çerçeve oluşturulmuştur. Bu tabloda 83 adet değer yer almaktadır.

Çerçeveye göre verilerin işlenmesi. 6. sınıf İngilizce ders kitabı 10 üniteden oluşmaktadır. Her bir ünite için belirlenen değerler listesine göre resimler, yazılar, dinleme etkinlikleri analiz edilmiş ve tabloya işlenmiştir. Bu aşamada verilerin güvenirliğini sağlamak amacıyla hem İngilizce hem de değerler eğitimi konusundaki bir uzmana random usulüne göre seçilmiş 20 kitap sayfası inceletilmiştir. Böylece güvenirliğin sağlanması için görüş birliği ve ayrılıkları belirlenmiştir. Araştırmanın güvenirlik hesaplamas1 için Miles ve Huberman'ın (1994) güvenirlik formülü [Güvenirlik = Görüş Birliği/ (Görüş Birliği +Görüş Ayrılı̆̆ı)] kullanılmıştır. Hesaplamanın sonunda araştırmanın güvenirliği \%95 çıkmıştır.

Bulguların tanımlanması. Elde edilen verilerde değerler nicelik olarak excel dosyasına aktarılmış ve her bir ünite için değerler grafikleri oluşturulmuştur. Böylece bulguların yorumlanmasına zemin hazırlanmıştır.

Bulguların yorumlanması. Bulguların tanımlanmasında oluşturulan grafikler betimlenerek yorumlanmış ve incelenen kitaplardan her bir değer için örnekler seçilerek bulgulamada kullanılmıştır.

\section{BULGULAR}

6. Sınıf İngilizce ders ve çalışma kitaplarında Yaşam (Life), Lezzetli Kahvaltı (Yummy Breakfast), Şehir Merkezi (Downtown), Hava ve Duygular (Weather And Emotions), Lunaparkta (At The Fair), Meslekler (Occupations), Tatiller (Vacations), Kitap Kurtlar1 (Bookworms), Gezegeni Kurtarmak (Saving the Planet) ve Demokrasi (Democracy) üniteleri yer almaktadır. Grafik 1'de altınc1 sınıf İngilizce ders kitabının tüm ünitelerinde yer alan yer alan değerler gösterilmiştir. 


\section{Grafik 1: Altıncı Sınıf İngilizce Ders Kitabında Yer Alan Değerlerin Bulunma Sıklıkları}

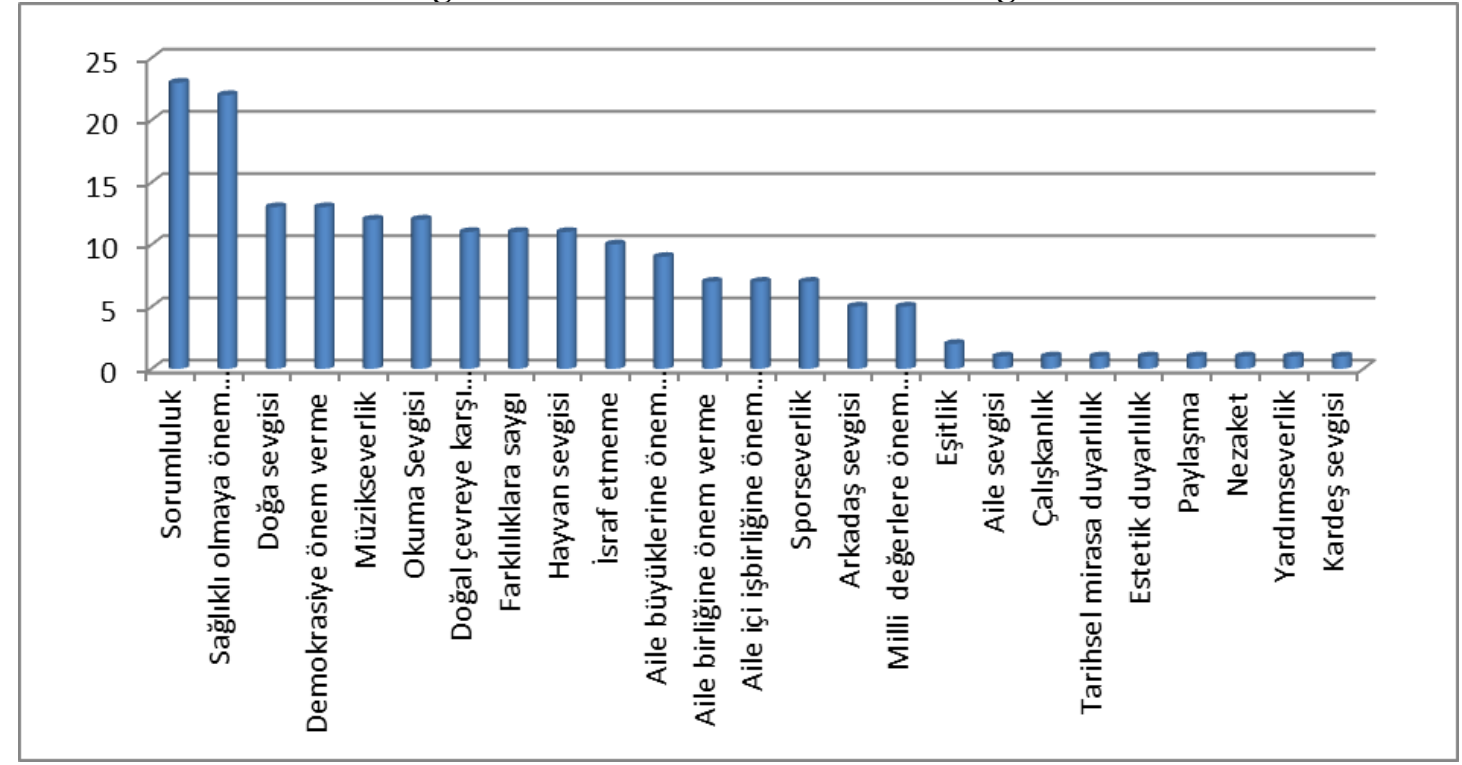

Kitaptaki tüm üniteler incelendiğinde kitapta yer alan değerlerin sıklıkları sırasıyla sorumluluk (23), sağllkl olmaya önem verme (22), demokrasiye önem verme (13), doğa sevgisi (13), müzikseverlik (12), okuma sevgisi (12), doğal çevreye karşı duyarlılık (11), farklllıklara saygı (11), hayvan sevgisi (11), israf etmeme (10), aile birliğine önem verme (9), aile birliğine önem verme (7), aile içi işbirliğine önem verme (7), sporseverlik (7), arkadaş sevgisi (5), milli değerlere önem verme (5), eşitlik (2), aile sevgisi (1), çalışkanlık (1), tarihsel mirasa duyarlılık (1), paylaşma (1), estetik duyarlılık (1), paylaşma (1), nezaket (1), yardımseverlik(1), kardeş sevgisi (1) şeklindedir. Bu değerler üniteler bazında analiz edilerek aşağıda sunulmuştur.

\section{1. Ünite: Yaşam (Life)}

Yaşam (Life) ünitesi öğrencilerin insanların düzenli olarak yaptıklarını anlatabilme (describing what people do regularly), basit sorular sorabilme (making simple inquiries), saatleri, günleri ve tarihleri söyleyebilme (telling the time, days and dates) kazanımlarına ulaşmasını amaçlayan bir ünitedir. İncelenen kitaplarda 17 sayfa bu ünite için ayrılmıştır. Grafik 1.1'de, 6. sınıf İngilizce kitabı "Yaşam" (Life) ünitesinde yer alan değerlere yer verilmiştir.

\section{Grafik 1.1: Yaşam (Life) Ünitesinde Yer Alan Değerlerin Bulunma Sıklıkları}

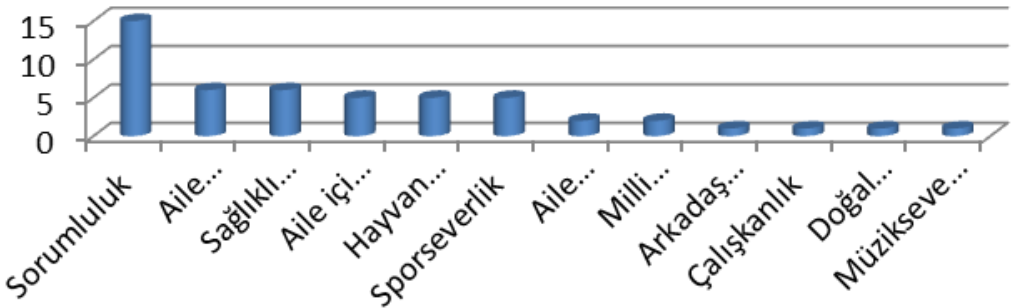

Grafik incelendiğinde; bu ünitede sorumluluk (15), aile büyüklerine önem verme (6), sağllkl olmaya önem verme (6), aile içi iş birliğine önem verme (5), hayvan sevgisi (5), sporseverlik (5), aile birliğine önem verme (2), milli değerlere önem verme (2), arkadaş sevgisi (1), çalışkanlık (1), doğal çevreye karşı duyarlılık (1), müzikseverlik (1) değerlerine yer verildiği görülmektedir. Görüldüğü üzere bu ünitede en çok sorumluluk (15) değeri yer almaktadır. Bu değer, çeşitli görsellerle örtük bir şekilde verilmekle birlikte daha çok ders çalışan bir çocuk görseliyle yansıtılmıştır. Görsel 1'de sorumluluk değerine vurgu yapan görsel ve yazılara örnekler verilmiştir. 

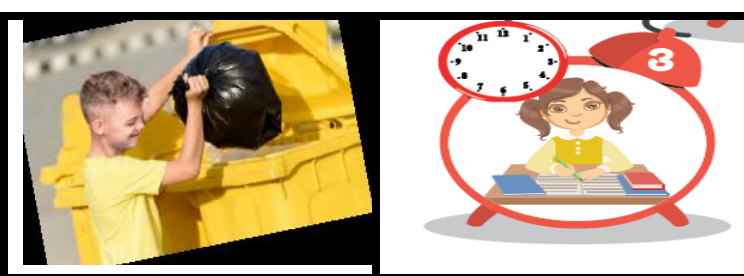

- At nine o'clock, she finishes all her homework.

(Saat 9’da tüm ödevlerini bitirir.)

Görsel 1. Sorumluluk (s.11, 12 ve 16)

Ders kitabında sorumluluk değerinden sonra ise sağglklı olmaya önem verme (6), aile içi iş birliğine önem verme (5), hayvan sevgisi (5) ve sporseverlik (5) değerleri birbirine yakın sıklıklarla yer almaktadır. Bu duruma yönelik örnekler Görsel 2, 3, 4,5, 6 ve 7'de yer almaktadır.

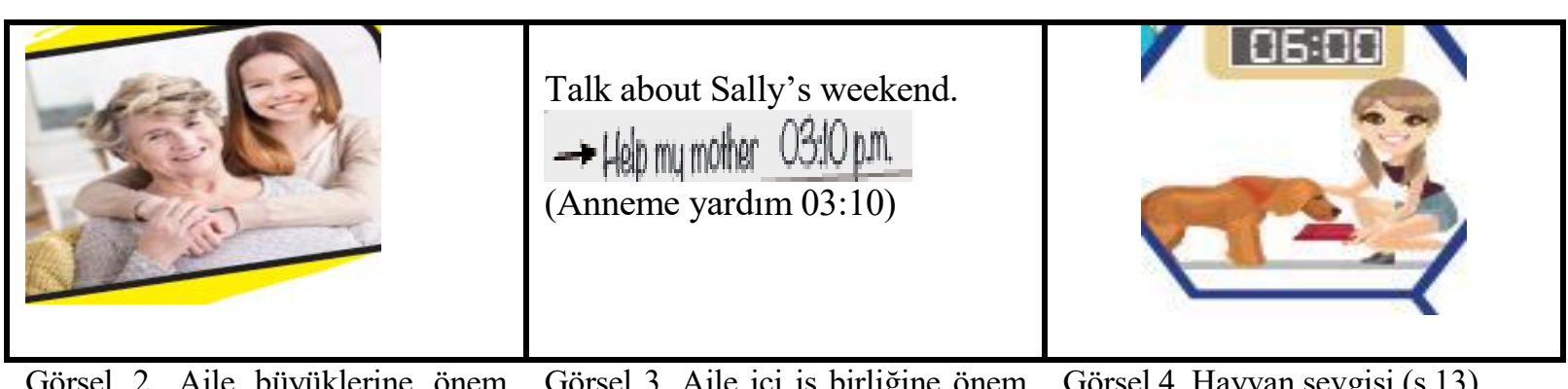

Görsel 2. Aile büyüklerine önem verme (s.10)

Görsel 3. Aile içi iş birliğine önem Görsel 4. Hayvan sevgisi (s.13) verme (s.14)

Görseller incelendiğinde; görsel 2'de küçük bir çocuk aile büyüğüne sarıldı̆̆ı, görsel 3'te ise çocuğun annesine yardım edeceği saat görülmektedir. Görsel 4'te ise bir köpeğe şefkat gösteren bir kız resmi mevcuttur.

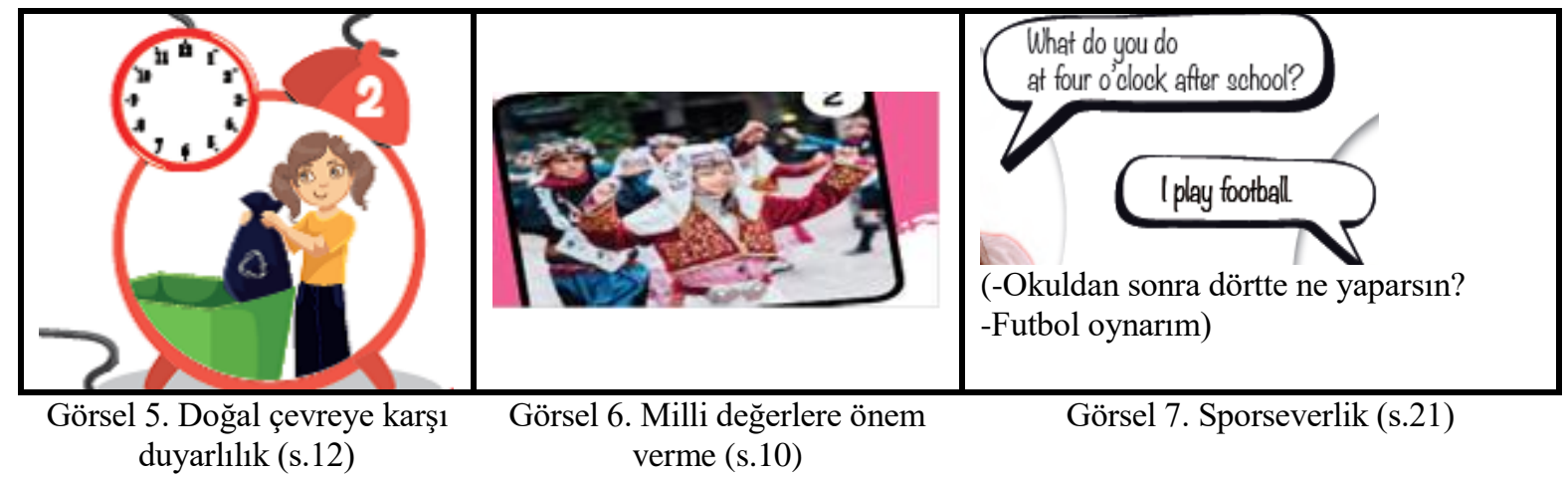

Görsel 5 görüldüğü üzere çöplerini çöpe atan bir kız yer alırken, Görsel 6'da Türk milli folklorunu oynayan öğrenciler bulunmaktadır. Ayrıca görsel 7 de bir spor dalı olan futboldan bahsedilmektedir.

\section{2. Ünite: Lezzetli Kahvaltı (Yummy Breakfast)}

Lezzetli Kahvaltı (Yummy Breakfast) ünitesi öğrencilerin kabul etme ve reddetme (accepting and refusing), insanların düzenli olarak neler yaptıklarını tarif etme (describing what people do regularly), hoşlandıkları ve hoşlanmadıkları şeyleri ifade etme (expressing likes and dislikes) kazanımlarına ulaşmasını amaçlayan bir ünitedir. İncelenen kitaplarda 19 sayfa bu ünite için ayrılmıştır. 6. Sınıf İngilizce kitab1 "Lezzetli Kahvaltı" (Yummy Breakfast) ünitesinde yer alan değerlere, grafik 1.2'de yer verilmiştir. 


\section{Grafik 1.2: Lezzetli Kahvaltı (Yummy Breakfast) Ünitesinde Yer Alan Değerlerin Bulunma Sıklıkları}

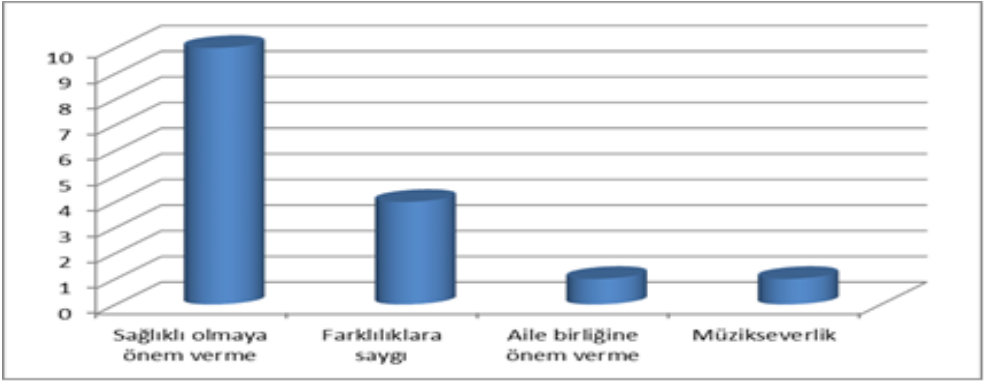

Grafik incelendiğinde; bu ünitede sağllklı olmaya önem verme (10), farklıllklara saygl (4), aile birliğine önem verme (1), müzikseverlik (1) değerlerine yer verildiği görülmektedir. Görüldüğü üzere bu ünitede en çok sağlıklı olmaya önem verme (10) değeri yer almaktadır. Bu değer çeşitli görseller örtük bir şekilde çoğunlukla sağlıklı besin görselleriyle yansıtılmıştır.

Görsel 8'de yer alan görsellerde, sağlıklı yiyecek ve abur cubur seçiminden bahsedilerek örtük bir şekilde sağlıklı olmaya önem verme değerine vurgu yapıldığı görülmektedir.

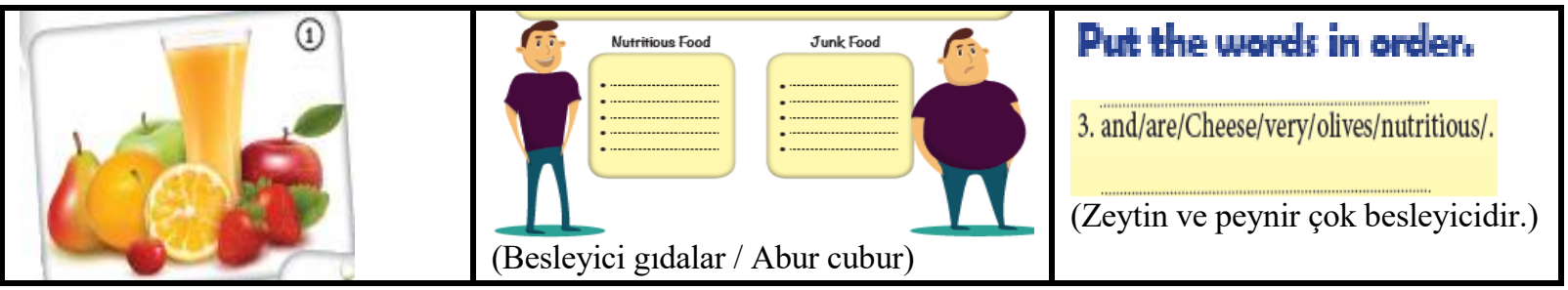

Görsel 8. Sağllklı olmaya önem verme (s.28, s.32, s.44)

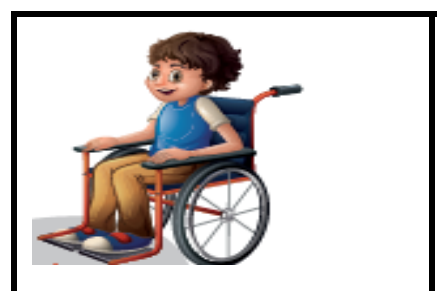

Görsel 9. Farkl111klara Sayg1 (s.33 ve 36)

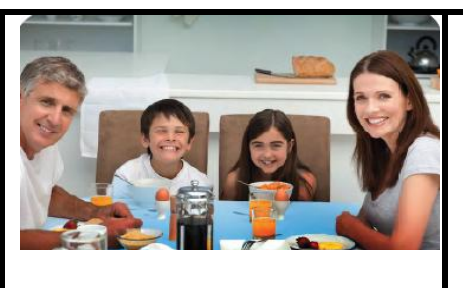

Görsel 10. Aile birliğine önem verme (s.27)

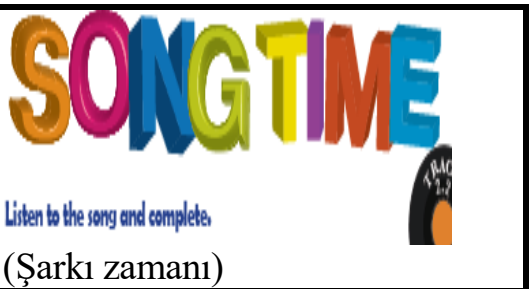

Görsel 11. Müzikseverlik (s.34)

Görsel 9'da engelli bir çocuk görseline yer verilirken, görsel 10'da bir ailenin birlikte sofrada yemek yemesine ve görsel 11 de öğrenilenleri şarkı ile tekrarına vurgu yapılmıştır.

\section{3. Ünite: Şehir Merkezi (Downtown)}

Şehir Merkezi (Downtown) ünitesi öğrencilerin yerleri tarif etme (describing places), insanların şu anda neler yaptıklarını tarif etme (describing what people are doing now), kazanımlarına ulaşmasını amaçlayan bir ünitedir. İncelenen kitapta 17 sayfa bu ünite için ayrılmıştır. 6. Sınıf İngilizce kitabı "Şehir Merkezi" (Downtown) ünitesinde yer alan değerlere grafik 1.3'te yer verilmiştir.

\section{Grafik 1.3: Șehir Merkezi (Downtown)Ünitesinde Yer Alan Değerlerin Bulunma Sıklıkları}

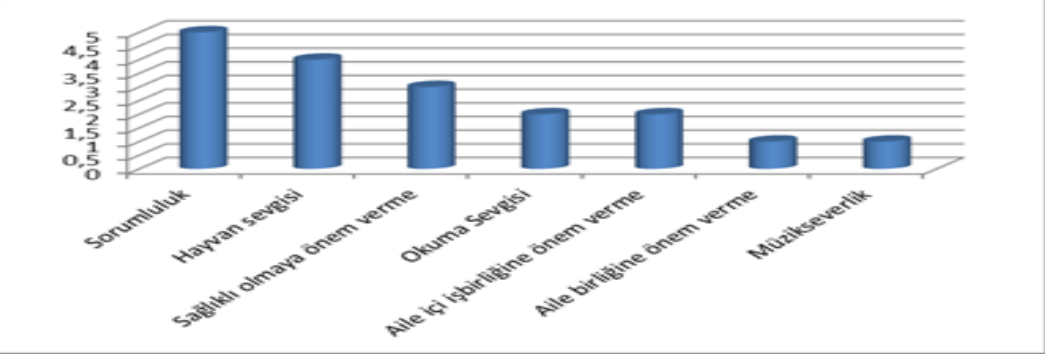


Grafik incelendiğinde; bu ünitede sorumluluk (5), hayvan sevgisi (4), săgllkll olmaya önem verme (3), okuma sevgisi (2), aile içi iş birliğine önem verme (2), aile birliğine önem verme (1), müzikseverlik (1) değerlerine yer verildiği görülmektedir. Görüldüğü üzere bu ünitede en çok sorumluluk (5) ve hayvan sevgisi (4) değerleri yer almaktadır. Bu değer çeşitli görsellerle örtük bir şekilde çoğunlukla sorumluluğunu yerine getiren çocuk görselleriyle yansıtılmıştır. Görsel 12'de bu durumu gösteren örneklere yer verilmiştir.

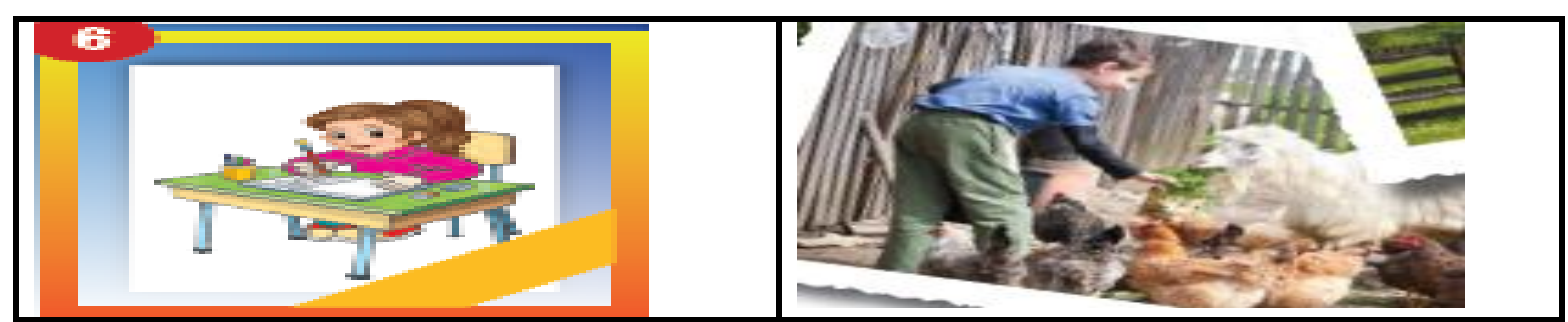

Görsel 12. Sorumluluk (s.54 ve 48)

Sorumluluk değerinden sonra ise sirasiyla hayvan sevgisi (4) ve sağllklı olmaya önem verme (3) okuma sevgisi (2), aile birliğine önem verme (1) ve müzikseverlik (1) değerleri verilmiştir. Görsel 13 incelendiğinde hayvanları beslemeye vurgu yapıldığı görülecektir.

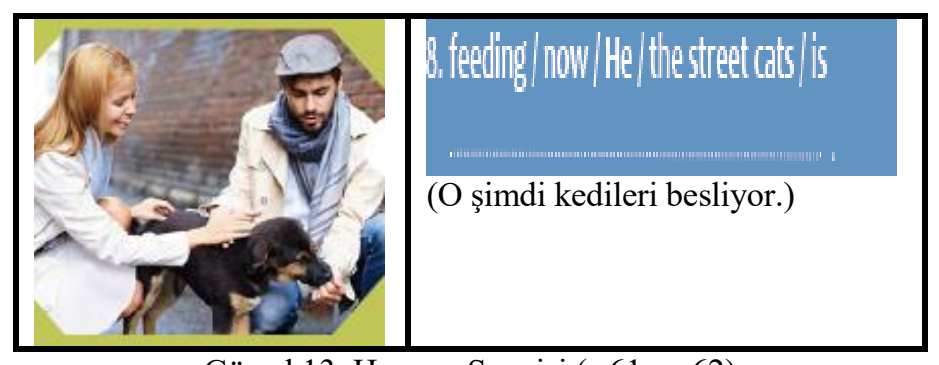

Görsel 13. Hayvan Sevgisi (s.61 ve 62)

Öte yandan görsel 14'te bir ailenin birlikte sofrada yemek yemesine ve görsel 15 'te de ögrrenilenleri şark1 ile tekrarı yapıldığına yer verilmiştir.

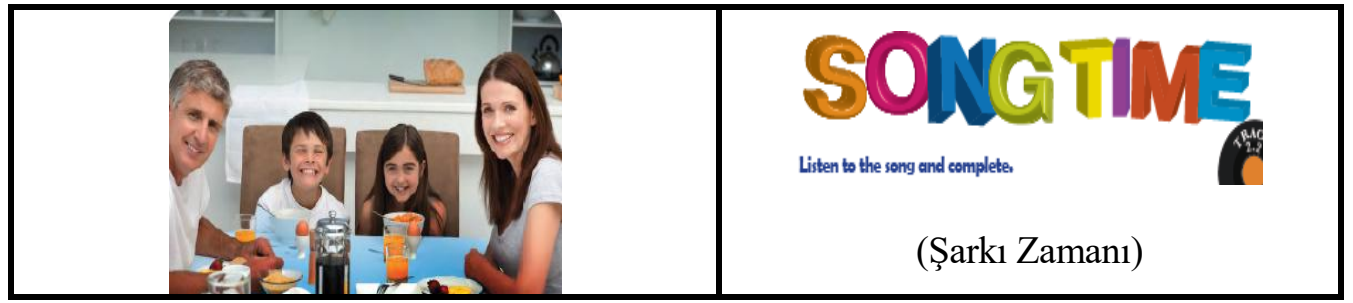

Görsel 14. Aile birliğine önem verme (s.27)

Görsel 15. Müzikseverlik (s.34)

\section{4. Ünite: Hava ve Duygular (Weather and Emotions)}

Hava ve duygular (weather and emotions) ünitesi öğrencilerin hava durumunu tarif etme (describing the weather), duygular1 ifade etme (expressing emotions) ve basit sorular sorabilme (making simple inquiries) kazanımlarına ulaşmasını amaçlayan bir ünitedir. İncelenen kitapta 17 sayfa bu ünite için ayrılmıştır. Grafik 1.4'te, 6. Sinıf İngilizce kitabı "Hava ve duygular" (Weather and Emotions) ünitesinde yer alan değerlere yer verilmiştir.

\section{Grafik 1.4: Hava ve Duygular (Weather and Emotions) Ünitesinde Yer Alan Değerlerin Bulunma Sıklıkları}

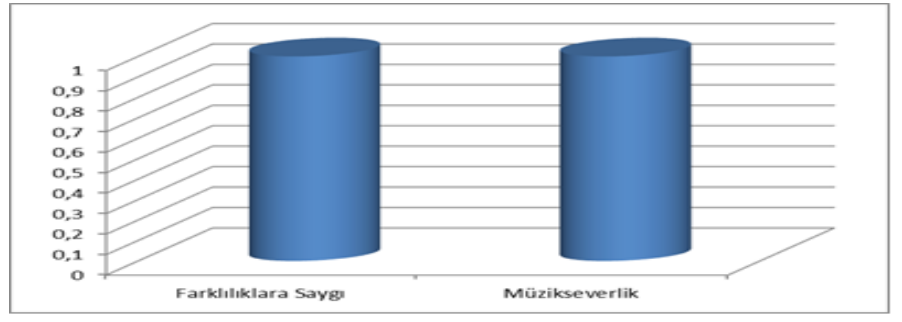


Grafikte görüldüğü üzere bu ünitede sadece farklıklara saygı (1) ve müzikseverlik (1) değerlerine yer verilmiştir. Farklılıklara saygı değerini ele alan görsel 16'da İtalyan arkadaşı Cemre'ye, Roma'daki hava durumunu anlatıp ve Cemre'nin yaşadığı şehirdeki havanın nasıl olduğunu soruyor. Böylelikle farklı iki ülke çocuğunun iletişimine yer verilmiştir. Öte yandan yine öğrenilenlerin tekrarı için bir müzik kullanıldığı görsel 17'de görülmektedir.

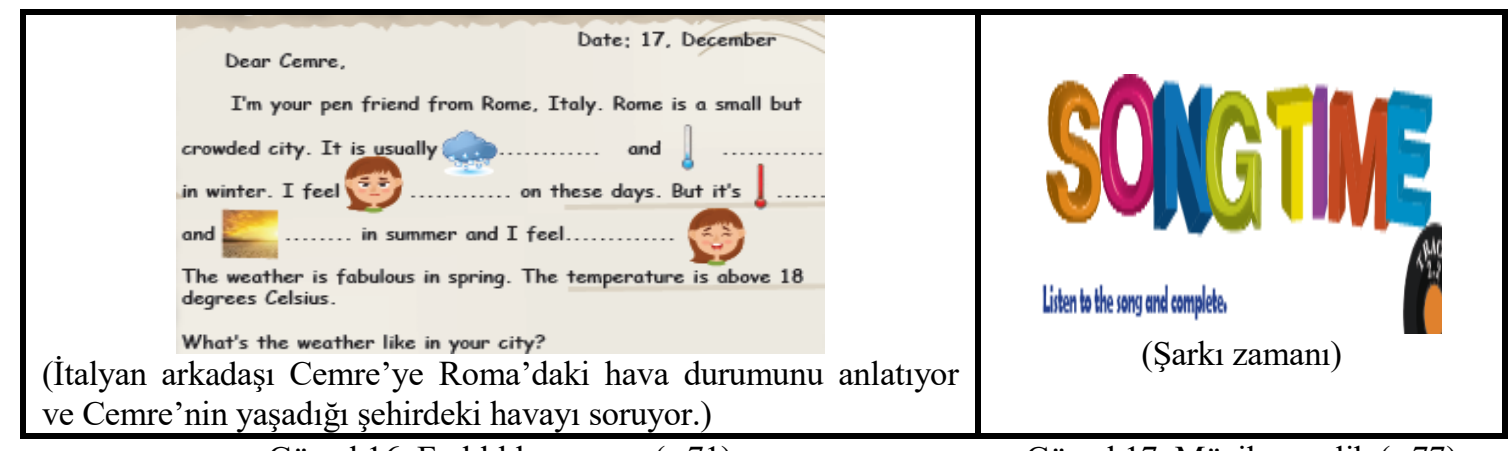

Görsel 16. Farklıklara sayg1 (s.71)

Görsel 17. Müzikseverlik (s.77)

\section{5. Ünite: Lunaparkta (At the Fair)}

Lunaparkta (At the Fair) ünitesi öğrencilerin hava durumunu tarif etme (describing the weather), duyguları ifade etme (expressing feelings), yerleri tarif etme (describing places), hoşlanılan ve hoşlanılmayan şeyleri ifade etme (expressing likes and dislikes) ve kişisel fikirleri ifade etme (stating personal opinions) kazanımlarına ulaşmasını amaçlayan bir ünitedir. İncelenen kitapta 17 sayfa bu ünite için ayrılmıştır. Grafik 1.5'te, 6. Sınıf İngilizce kitabı "Lunaparkta" (At the Fair) ünitesinde yer alan değerlere yer verilmiştir.

\section{Grafik 1.5: Lunaparkta (At the Fair) Ünitesinde Yer Alan Değerlerin Bulunma Sıklıkları}

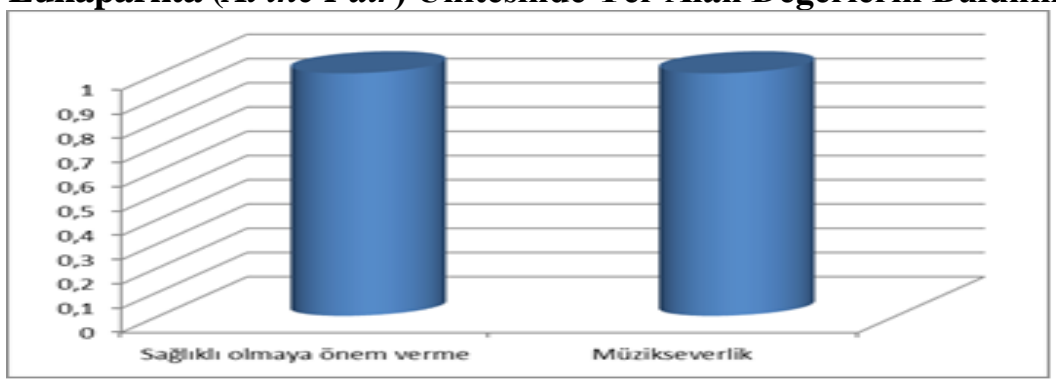

Grafik incelendiğinde bu ünitede sadece sağllkl olmaya önem verme (1) ve müzikseverlik (1) değerlerine yer verildiği görülmektedir. Değerlere çok fazla yer verilmediği bu ünitede "-Köy hakkında ne düşünüyorsun? -Etkileyici olduğunu düşünüyorum. Köylerde doğal ve besleyici yiyecekler bulabilirsin. Katıllyorum. Ayrıca, temiz hava da var." (Bkz. Görsel 18) diyaloğuyla sağlıklı olmaya önem verme değerinden bahsedilmektedir. Öte yandan diğer ünitelerde olduğu gibi bu ünitede de şarkı zamanı etkinliği ile öğrencilerin müzikle öğrendiklerini tekrarlatmak amaçlanmıştır. (Bkz. Görsel 19)

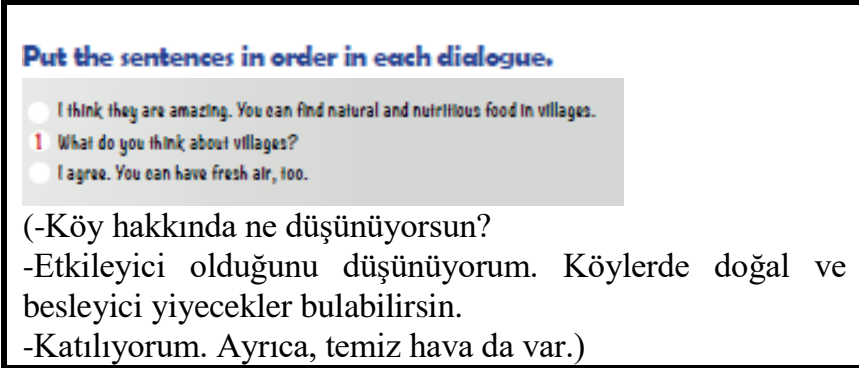

Görsel 18. Sağlıklı olmaya önem verme (s.97)

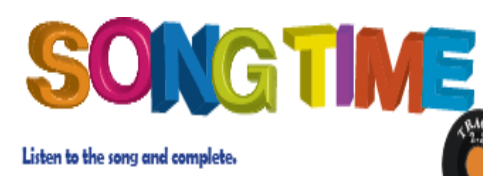

(Şarkı Zamanı)

Görsel 19. Müzikseverlik (s.93) 


\section{6. Ünite: Meslekler (Occupations)}

Meslekler (Occupations) ünitesi öğrencilerin geçmiş meslekler hakkında konuşma (talking about past occupations), kişisel sorular sorma (asking personal questions), zamanı, günleri ve tarihleri söyleme (telling the time, days and dates) kazanımlarına ulaşmasını amaçlayan bir ünitedir. İncelenen kitaplarda 19 sayfa bu ünite için ayrılmıştır. Grafik 1.6'da, 6. Sınıf İngilizce kitabı "Meslekler" (Occupations) ünitesinde yer alan değerlere yer verilmiştir.

\section{Grafik 1.6: Meslekler (Occupations) Ünitesinde Yer Alan Değerlerin Bulunma Sıklıkları}

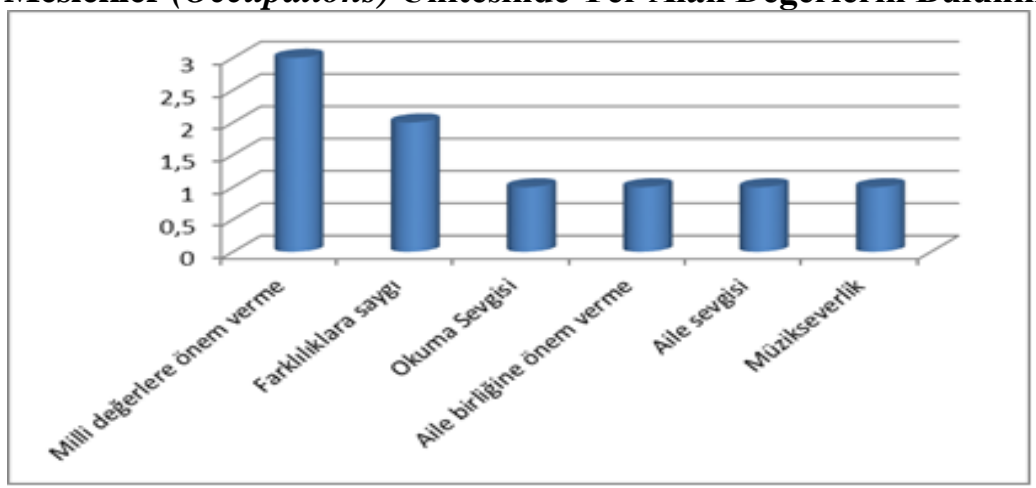

Grafik incelendiğinde; bu ünitede milli değerlere önem verme (3), farklllıklara sayg (2), okuma sevgisi (1), aile birliğine önem verme (1), aile sevgisi (1), müzikseverlik (1) değerlerine yer verildiği görülmektedir. Görüldüğü üzere bu ünitede en çok milli değerlere önem verme (3) değeri yer almaktadır. $\mathrm{Bu}$ değer çoğunlukla Türk büyüklerinden bahsedilerek yansıtılmıştır.

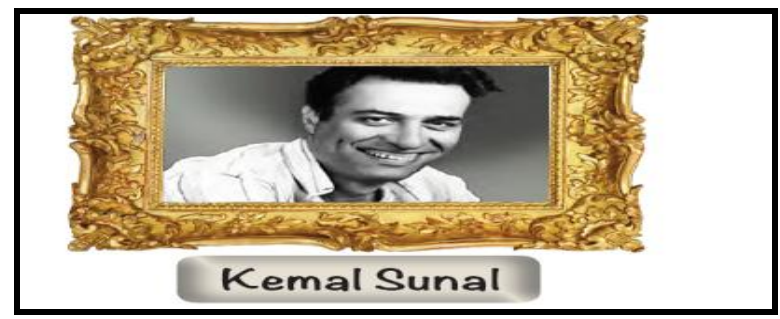

Görsel 20. Milli değerlere önem verme (s.108)

Milli değerlere önem verme değerinin dışında farklllıklara saygl (2) okuma sevgisi (1), aile birliğine önem verme (1), aile sevgisi (1), müzikseverlik (1) değerlerine yer verilmiştir.

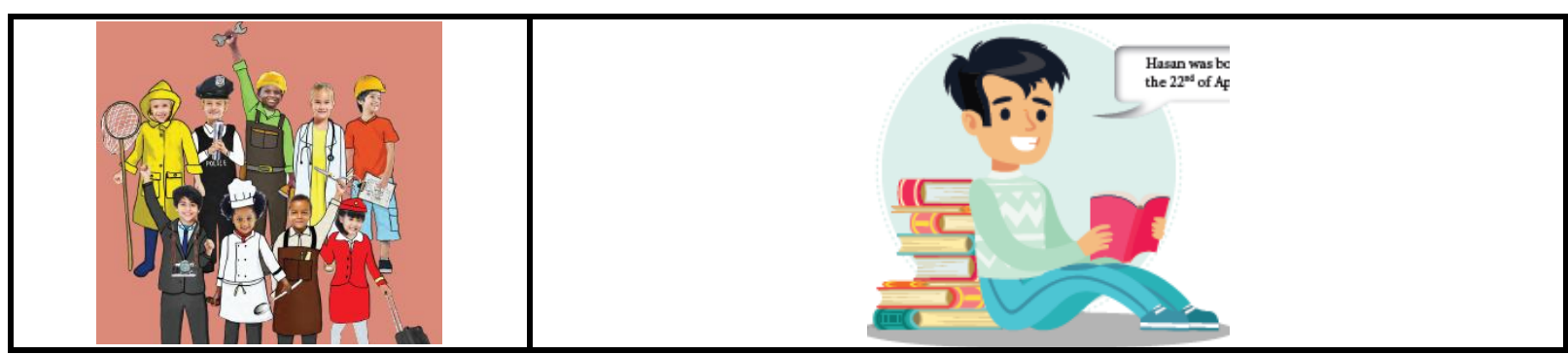

Görsel 21. Farkl11ıklara sayg1

Görsel 22. Okuma Sevgisi (s.113) (s.101)

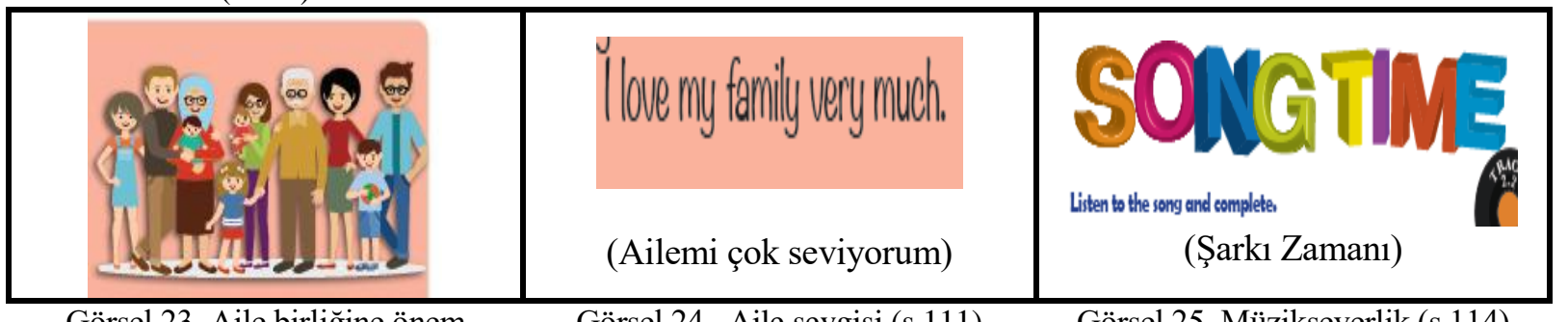

Görsel 23. Aile birliğine önem verme (s.111)

Görsel 24. Aile sevgisi (s.111)

Görsel 25. Müzikseverlik (s.114) 
Bu ünite; görsel 21'de farklı meslek gruplarını bir araya getirerek "farklılıklara saygı" değerini, görsel 22 'de kitap okuyan çocuk görseliyle "okuma sevgi" sini, görsel 23'te kalabalık bir aile resmine yer vererek "aile birliğine önem verme" değerini, görsel 24'te "ailemi çok seviyorum" yazısıyla "aile sevgisi" ni ve diğer ünitelerde olduğu gibi şarkı ile öğrenilenlerin tekrarını sağlayarak "müzikseverlik" (bkz. Görsel 25) değerini örtük bir şekilde ele almıştır.

\section{7. Ünite: Okuldan Sonra (After School)}

Okuldan sonra (After School) ünitesi öğrencilerin geçmiş olaylar hakkında konuşma (talking about past events), basit sorular sorma (making simple inquiries) kazanımlarına ulaşmasını amaçlayan bir ünitedir. İncelenen kitaplarda 17 sayfa bu ünite için ayrılmıştır. Grafik 1.7'de, 6. Sınıf İngilizce kitabı "Okuldan Sonra" (After School) ünitesinde yer alan değere yer verilmiştir.

\section{Grafik 1.7: Okuldan Sonra (After School) Ünitesinde Yer Alan Değerlerin Bulunma Sıklıkları}

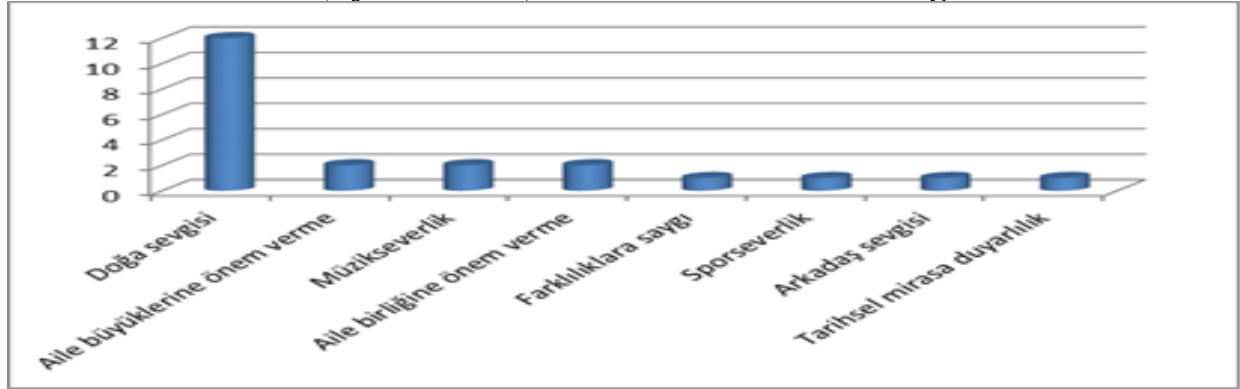

Grafikte görüldüğü üzere bu ünitede doğa sevgisi (12), aile büyüklerine önem verme (2), müzikseverlik (2), aile birliğine önem verme (2), farklılıklara sayg (1), sporseverlik (1), arkadaş sevgisi (1), tarihsel mirasa duyarlılık (1) değerlerine yer verildiği görülmektedir. Görüldüğü üzere bu ünitede en çok doğa sevgisi (12) değeri yer almaktadır ve çoğunlukla doğada yapılan etkinlik görselleri ve yazılarıyla verilmiştir. (Bkz. Görsel 26).

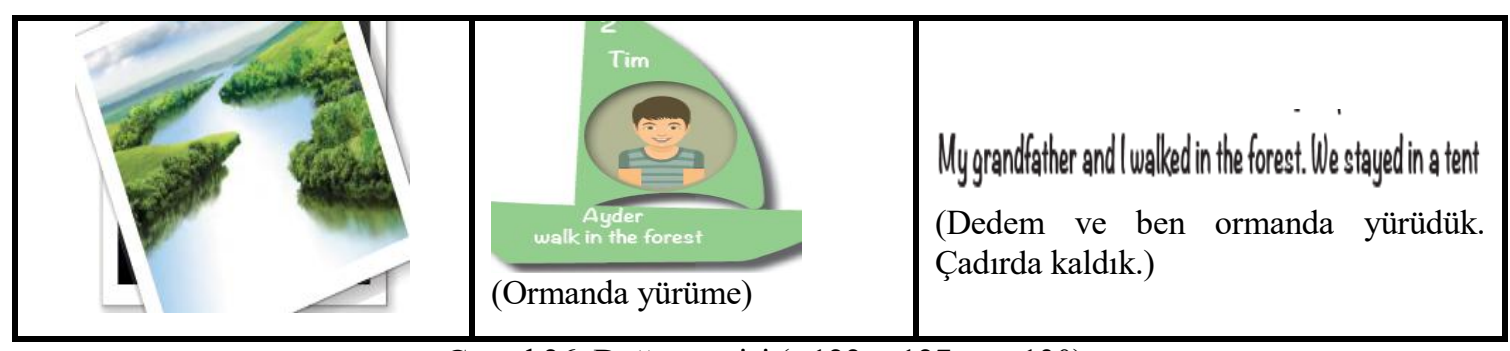

Görsel 26. Doğa sevgisi (s.122, s.127 ve s.130)

Doğa sevgisi değeri dışında aile büyüklerine önem verme (2), müzikseverlik (2), aile birliğine önem verme (2), farkliliklara saygl (1), sporseverlik (1), arkadaş sevgisi (1), tarihsel mirasa duyarlılı (1) değerleri verilmiştir.

\begin{tabular}{|l|l|}
\hline Hi,everybody! I'm Demir. I'm a student at a primary school. Ivisited my grandparents & \multicolumn{1}{c|}{$\begin{array}{c}\text { Hl, Pm Emel. Last summer my } \\
\text { famly and I ware in Fethlye. We stayed in }\end{array}$} \\
last summer holiday. They live in a village. There are high mountains and a big forest around \\
$\begin{array}{l}\text { (Herkese selam! Ben Demir. İlkokulda okuyorum. } \\
\text { Geçen yaz tatilinde dede ve ninemi ziyaret ettim.) }\end{array}$ & $\begin{array}{l}\text { (Merhaba ben Emel. Geçen yaz ailemle birlikte } \\
\text { Fethiye'deydik.) }\end{array}$ \\
\hline
\end{tabular}

Görsel 27. Aile büyüklerine önem verme (s.130) Görsel 28. Aile birliğine önem verme (s.124)

Görsel 27'de yer alan yazıda aile büyüklerine ziyaretten bahsederken, görsel 28'de aileyle birlikte vakit geçirmekten söz edilmektedir. Görsel 29'da tarihsel bir yapıya yer verilirken, görsel 30' da farklı ülkelerin sahip olduğu değerlerin görseline yer verilmiştir. Ayrıca Görsel 30'da arkadaş ziyaretinden bahseden bir yazıya yer verilerek "arkadaş sevgisi” değeri örtük bir şekilde ele alınmıştır. 


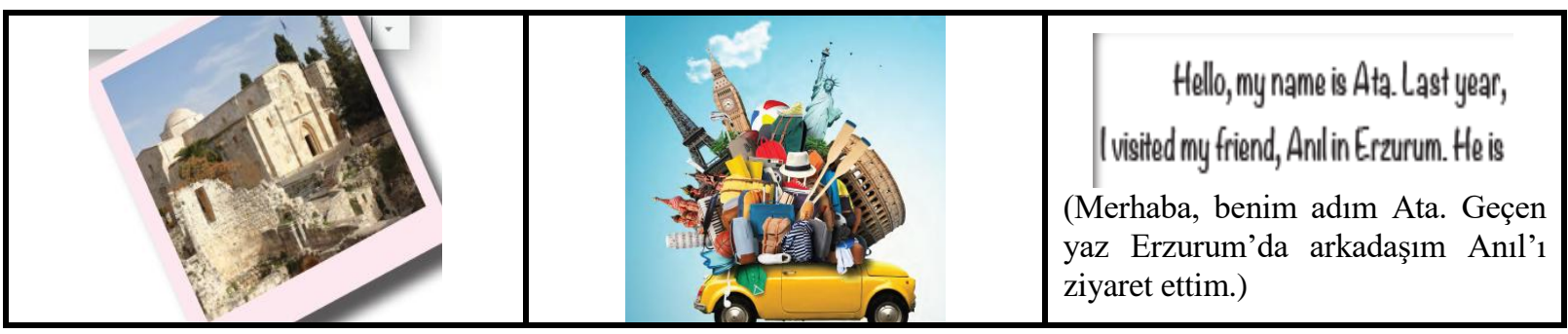

Görsel 29. Tarihsel mirasa duyarlilık (s.132)

Görsel 30. Farkl1lıklara sayg1 (s.121)

\begin{tabular}{|c|c|}
\hline $\begin{array}{c}\text { 4. My brother plays volleyball with his friends yesterday. } \\
\text { (Erkek kardeşim dün arkadaşlariyla } \\
\text { basketbol oynadi.) }\end{array}$ & \\
\hline
\end{tabular}

Görsel 32. Sporseverlik (s.135)

Görsel 33. Müzikseverlik (s.136)

Öte yandan Görsel 32'de basketbol sporundan bahsedilerek "sporseverlik değeri”, görsel 33'te piyano, gitar çalmaktan bahsedilerek "müzikseverlik" değerine yer verilmiştir.

\section{8. Ünite: Kitap Kurtları (Bookworms)}

Kitap Kurtları (Bookworms) ünitesi öğrencilerin geçmiş olaylar hakkında konuşma (talking about past events), kişilerin ve eşyaların konumu hakkında konuşma (talking about locations of things and people) kazanımlarına ulaşmasını amaçlayan bir ünitedir. İncelenen kitaplarda 19 sayfa bu ünite için ayrılmıştır. Grafik1.8'de, 6. Sınıf İngilizce kitabı "Kitap Kurtları" (Bookworms) ünitesinde yer alan değerlere yer verilmiştir.

\section{Grafik 1.8: Kitap Kurtları (Bookworms) Ünitesinde Yer Alan Değerlerin Bulunma Sıklıkları}

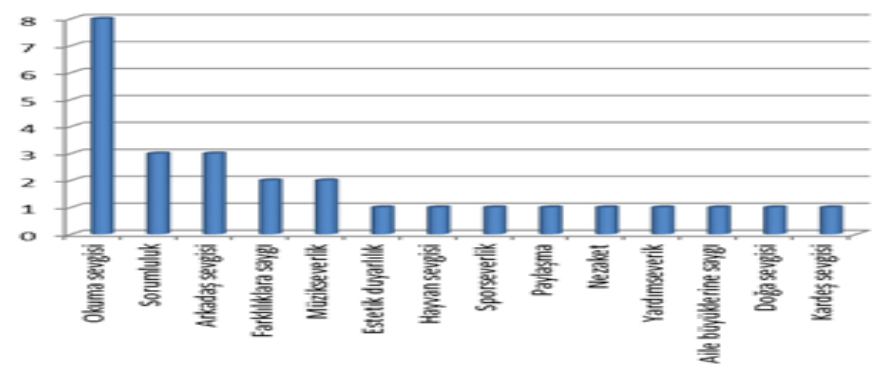

Grafik incelendiğinde; bu ünitede okuma sevgisi (12), sorumluluk (3), arkadaş sevgisi (3), farklilıklara saygl (2), müzikseverlik (2), estetik duyarlılık (1), hayvan sevgisi (1), sporseverlik (1), paylaşma (1), nezaket (1), yardımseverlik (1), aile büyüklerine saygl (1), doğa sevgisi (1), kardeş sevgisi (1) değerlerine yer verildiği görülmektedir. Ünitenin başlığından da anlaşılabileceği üzere bu ünitede en çok okuma sevgisi (8) değeri yer almaktadır. Bu değer, bu ünitede işlenen değerlerin büyük kısmını oluşturmaktadır ve çoğunlukla okumakta olan kişi görselleri veya okuma konusunda konuşmalar yapan kişilerin sözleriyle verilmiştir. (Bkz. Görsel 34).

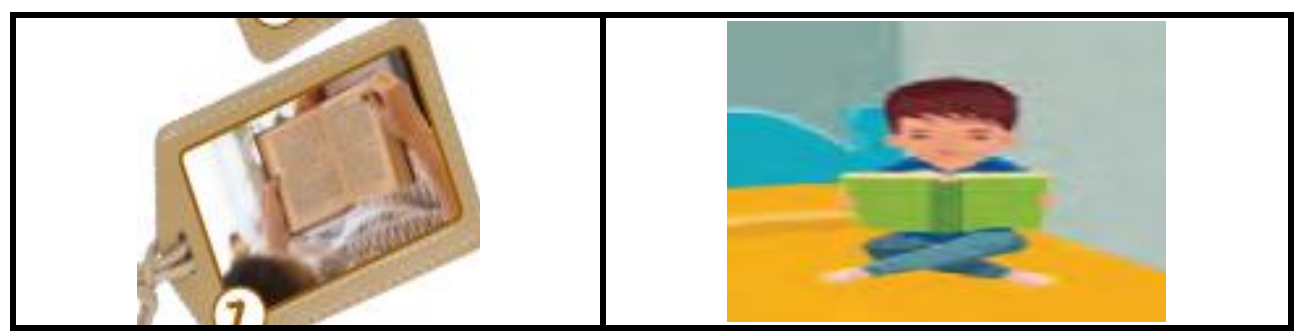

Görsel 34. Okuma sevgisi (s.141 ve s. 142) 
Okuma sevgisi değeri haricinde sorumluluk (3), arkadaş sevgisi (3), farklılıklara saygı (2) müzikseverlik (2), estetik duyarlilik (1), hayvan sevgisi (1), sporseverlik (1), paylaşma (1), nezaket (1), yardimseverlik (1), aile büyüklerine saygı (1), doğa sevgisi (1), kardeş sevgisi (1) değerleri verilmiştir.

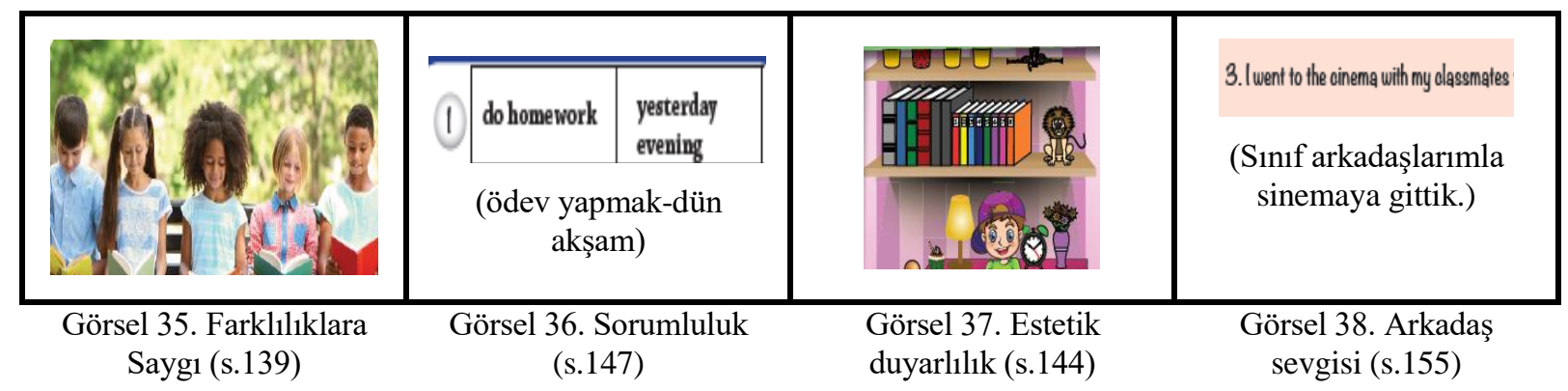

Farklı milletten çocukların yer aldığı görsel 35 ile "farklılıklara saygı" değeri, öğrenci için bir sorumluluk olan ödeve vurgu yapan görsel 36 ile "sorumluluk" değeri, düzenden bahseden görsel 37 ile "estetik duyarlılık" değeri ve sınıf arkadaşlarıyla etkinlik yapmaktan bahseden görsel 38 ile "arkadaş sevgisi" değeri ele alınmıştır.

\begin{tabular}{|c|c|c|}
\hline $\begin{array}{l}\text { loalled Sue later and shelent me her skates. } \\
\text { (Sonra Sue'yu aradım ve bana } \\
\text { patenlerini ödünç verdi.) }\end{array}$ & 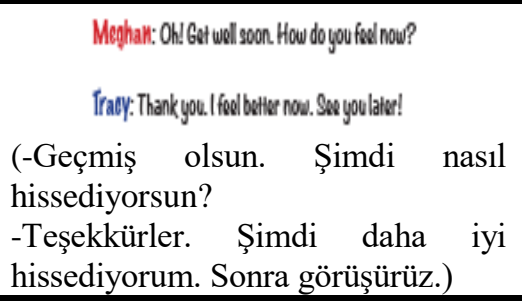 & 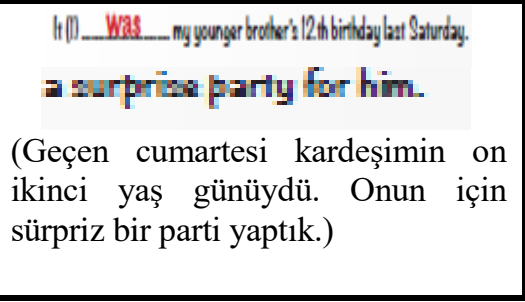 \\
\hline Görsel 39. Paylaşma (s.154) & Görsel 40. Nezaket (s.151) & Görsel 41. Kardeş sevgisi (s.156) \\
\hline $\begin{array}{l}\text { :Ihad an loeskatlng course yesterday. } \\
\text { (Dün buz pateni kursum vard1.) }\end{array}$ & SOMT TIC & \\
\hline
\end{tabular}

$\mathrm{Bu}$ ünitede yer alan paylaşma değeri ödünç verme eylemiyle (bkz. Görsel 39), nezaket değeri nezaket içeren diyaloglarla (bkz. Görsel 40), kardeş sevgisi değeri kardeşe yapılan bir sürpriz eylemiyle (bkz. Görsel 41), sporseverlik değeri buz pateni yapma eylemiyle (bkz. Görsel 42), hayvan sevgisi değeri köpeğe yiyecek verme eylemiyle (bkz. Görsel 44) ve son olarak diğer ünitelerde olduğu gibi müzikseverlik değeri şarkı zamanı etkinliğiyle (bkz. Görsel 43) verilmeye çalışılmıştır.

\section{9.Ünite: Gezegeni Kurtarma (Saving The Planet)}

Gezegeni Kurtarma (Saving The Planet) ünitesi öğrencilerin basit yönergeler verme ve cevaplama (giving and responding to simple instructions) kazanımlarına ulaşmasını amaçlayan bir ünitedir. İncelenen kitaplarda 15 sayfa bu ünite için ayrılmıştır. Grafik 1.9'da, 6. Sınıf İngilizce kitabı "Gezegeni Kurtarma" (Saving The Planet) ünitesinde yer alan değerlere yer verilmiştir. 


\section{Grafik 1.9: Gezegeni Kurtarma (Saving The Planet) Ünitesinde Yer Alan Değerlerin Bulunma Sıklıkları}

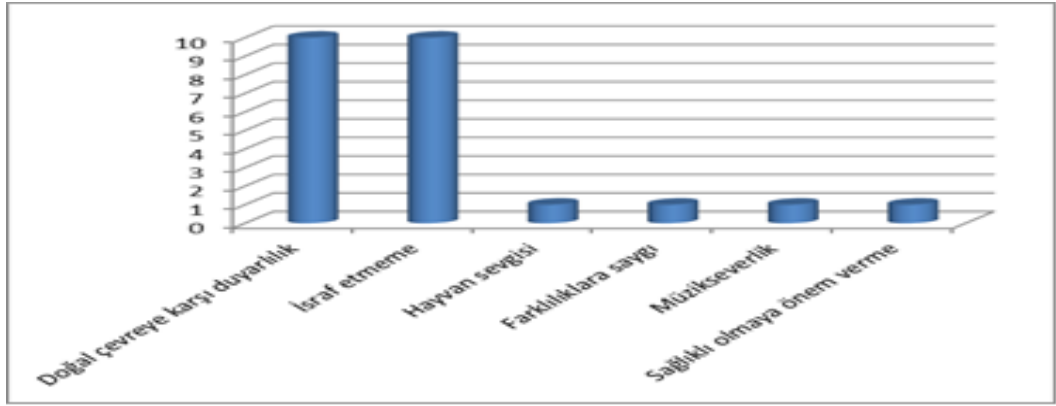

Grafikte görüldüğü üzere bu ünitede doğal çevreye karşı duyarlılık (10), israf etmeme (10), hayvan sevgisi (1), farkllliklara saygl(1), müzikseverlik (1), sağllk olmaya önem verme (1) değerlerine yer verildiği görülmektedir. Ünitenin adından da tahmin edilebileceği gibi bu ünitede en çok doğal çevreye karşı duyarlılık (8) ve israf etmeme (10) değerleri yer almaktadır. Doğal çevreye karşı duyarlılık değeri, görseller ve tavsiyelerle verilmiştir. İsraf etmeme değeri ise çoğunlukla geri dönüşüm konusu ile verilmiştir. (Bkz. Görsel 45 ve 46)

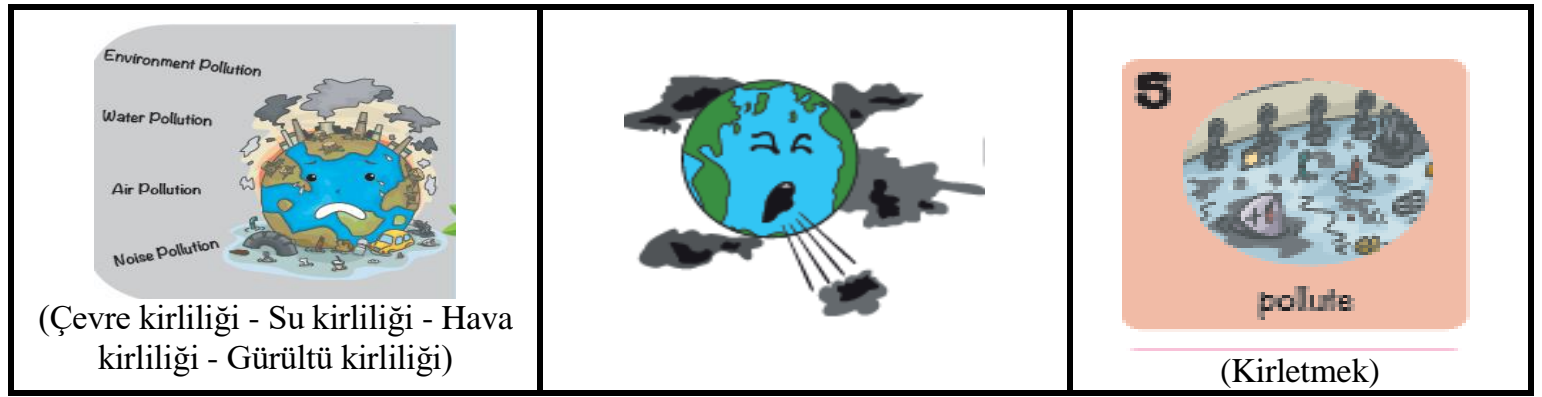

Görsel 45. Doğal çevreye karşı duyarlılık (s.164, s.165 ve s.168)

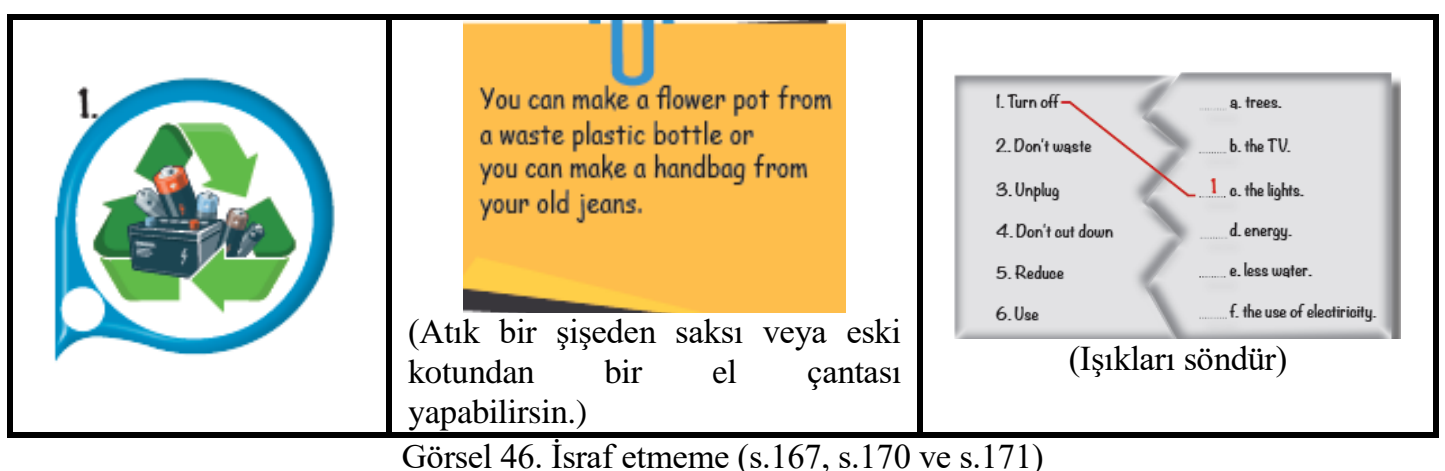

Doğal çevreye karşı duyarlılık ve israf etmeme değerlerinin dışında hayvan sevgisi (1), farklılıklara saygı (1), müzikseverlik (1), sağllk olmaya önem verme (1) değerleri verilmiştir.

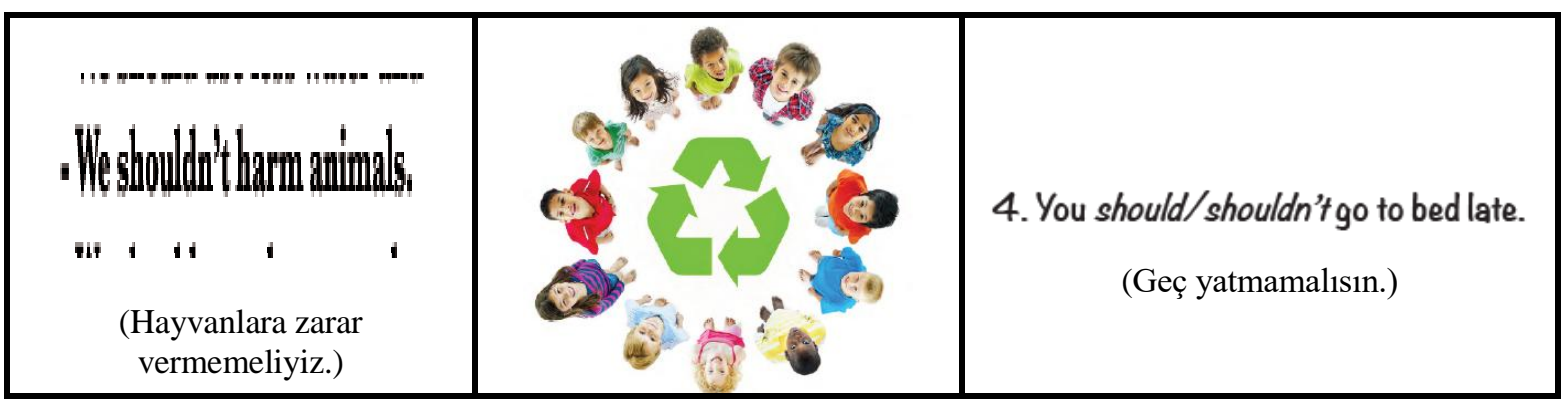




$\begin{array}{ccc}\begin{array}{c}\text { Görsel 47. Hayvan sevgisi } \\ \text { (s.162) }\end{array} & \text { Görsel 48. Farklılıklara sayg1 } & \text { Görsel 49. Sağlıklı olmaya önem verme } \\ \text { (s.159) } & \text { (s.172) }\end{array}$

Görsel 47'de "Hayvanlara zarar vermemeliyiz." yazısı yer almaktadır. Ayrıca görsel 48 de farklı ülkelerden çocuklara ve görsel 49'da geç yatmayarak sağllğın korunabileneceğine örtük bir şekilde vurgu yapılmıştır.

\section{0. Ünite: Demokrasi (Democracy)}

Demokrasi (Democracy) ünitesi öğrencilerin basit sorular sorma (making simple inquiries), geçmiş olaylar hakkında konuşma (talking about past events) ve bir işleyişin aşamaları hakkında konuşma (talking about the stages of a procedure) kazanımlarına ulaşmasını amaçlayan bir ünitedir. İncelenen kitaplarda 14 sayfa bu ünite için ayrılmıştır. Grafik 1.10'da 6. Sınıf İngilizce kitabı "Demokrasi”" (Democracy) ünitesinde yer alan değerlere yer verilmiştir.

\section{Grafik 1.10: Demokrasi (Democracy)Ünitesinde Yer Alan Değerlerin Bulunma Sıklıkları}

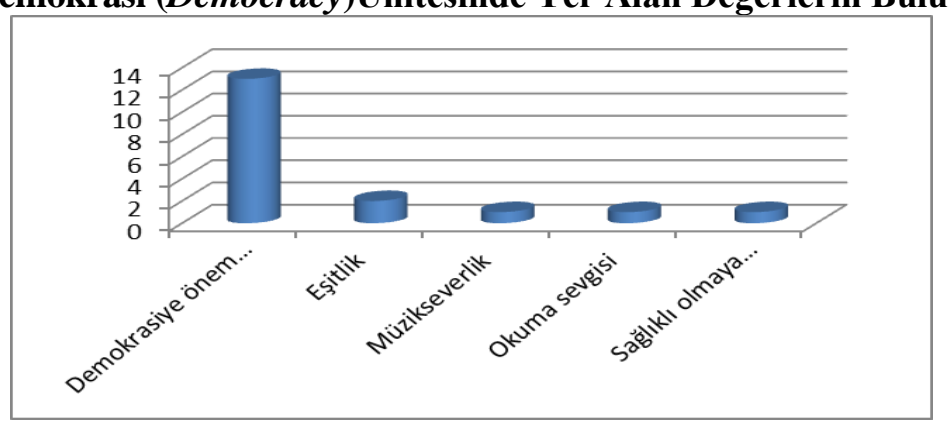

Grafik 10'da görüldüğü üzere bu ünitede demokrasiye önem verme (13), eşitlik (2), okuma sevgisi (1), müzikseverlik (1), sağllk olmaya önem verme (1) değerlerine yer verildiği görülmektedir. Ünitenin demokrasi konusunu ele aldığından en çok demokrasiye önem verme (13) değerine yer verilmiştir. (Bkz. Görsel 50)

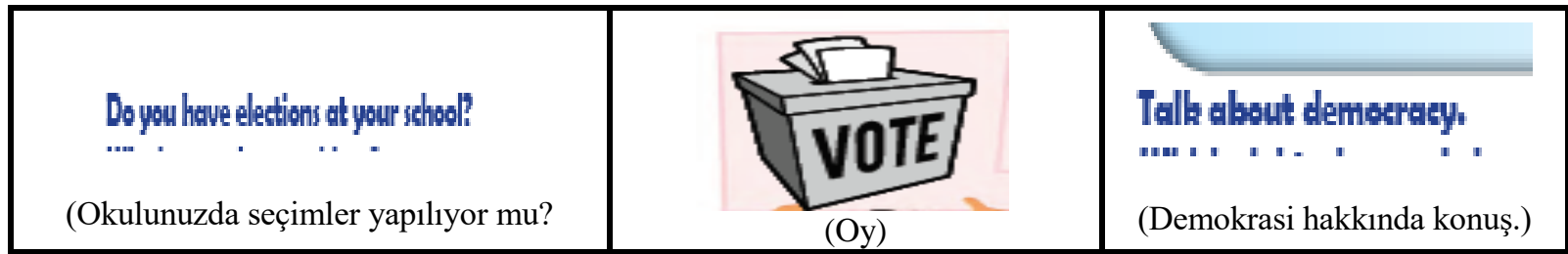

Görsel 50. Demokrasiye önem verme (s.176, s.179, s.185)

Demokrasiye önem verme değeri dışında eşitlik (2), okuma sevgisi (1), müzikseverlik (1), sağlık olmaya önem verme (1) değerleri verilmiştir.

\begin{tabular}{|c|c|}
\hline \multicolumn{1}{|c|}{$\begin{array}{l}\text { We are all equal. } \\
\text { We are all free. } \\
\text { We are all dlfferent. } \\
\text { We are all the same. }\end{array}$} & She thinks we must eqa more nutrilious food \\
$\begin{array}{l}\text { (Hepimiz eşitiz, özgürüz, farklıyız, } \\
\text { aynıyz.) }\end{array}$ & $\begin{array}{l}\text { (Daha besleyici gıdalar yememiz gerektiğini } \\
\text { düşünüyor.) }\end{array}$ \\
\hline \multicolumn{1}{|c|}{ Görsel 51. Eşitlik (s.184) } & Görsel 52. Sağlıklı olmaya önem verme (s.159)
\end{tabular}

Görsel 51'de görüldüğü üzere eşitlik değerinden “Hepimiz eşitiz, özgürüz, farklıyız, aynıyı." şeklinde bahsedilmektedir. Ayrıca "Daha besleyici gıdalar yememiz gerektiğini düşünüyor." söylemiyle de sağlıklı olmaya önem verme değerinden bahsedildiği anlaşılmaktadır.

\section{SONUÇ, TARTIŞMA ve ÖNERILER}

Yapılan bu çalışmada elde edilen bulgular 1şığında, 2019 yılında okullarımızda 6. sınıflarda kullanılan İngilizce ders kitaplarının hemen tüm ünitelerinde değer kazanımlarına yer verildiği görülmüştür. Ayrıca öğrenciler tarafindan edinilmesi beklenen değerlerin, çoğunlukla işlenen konuların içerisinde örtük olarak kazanmalarının amaçlandığı fark edilmiştir. Zira değer kazanımlarına ilişkin materyaller (görsel, 
işitsel vb.), çoğunlukla işlenen ünite içerisine konu bütünlüğü gözetilerek yerleştirilmiştir. Bununla birlikte değerlerin doğrudan telkin edilmesine yönelik yazı ver görsellere de kitapta rastlanmıştır. $\mathrm{Bu}$ duruma sağlıklı olmaya önem verme, hayvanseverlik gibi bazı değerlere ilişkin telkinler örnek gösterilebilir. Kitapta oluşturulan ünitelerde bazı değerler, ünite bazında öne çıkmış olsa da değerler karışık olarak sunulmuştur. Bununla birlikte belirlenen ünitelerdeki konuların değer aktarımına uygunluğu gözetilerek seçildiği söylenebilir. Bu sayede birçok değer geniş bir yelpaze içerisinde verilmiştir. Verilen değerlerin, daha çok görsellere ve basit cümlelere dayandırıldığı görülmüş olup bu durumun 6. sınıf seviyesindeki öğrencilerin İngilizce okuma, anlama ve kendini ifade etme beceri düzeylerine uygun olduğu düşünülmektedir.

Geçmişte yapılan bazı araştırmalarda farklı derslerde, değer aktarımına ilişkin birtakım aksaklıklar belirtilmiştir. Örneğin 2008, 2011 ve 2013 yıllarında 6, 7 ve 8. sınıflarda Türkçe ders kitaplarındaki değer aktarımına ilişkin yapılan bazı araştırmalarda, kitaplarda yer alan metinlerin değer edinimi için uygun olmadığı, değerlerin dengesiz olarak dağıtıldığı veya değer kazanımlarıyla bütünlük oluşturmadığına dair vurgular yapılmıştır. Ayrıca değer aktarımında kullanılan kitapların estetiğine önem verilmesi gerektiği söylenmiştir. (Somuncu, 2008; Doğan ve Gülüşen, 2011; Kaygana, Yapıcı ve Aytan, 2013). Bununla birlikte 2014 yilında 3. sınıf hayat bilgisi dersi kitabının temel evrensel değerleri içermesine ilişkin yapılan araştırmada, kitaplar yeterli bulunmuş fakat barış, temizlik, misafirperverlik gibi birkaç değerin daha fazla vurgulanması gerektiği sonucuna varılmıştır (Candan ve Ergen 2014). 4. ve 5. sınıf düzeyinde sosyal bilgiler dersine ilişkin yapılan bir araştırmada, ders kitaplarında birçok değerin uygun şekilde verildiği görülmüş fakat temizlik, dürüstlük ve hoşgörü değerlerinin hedeflenen ögrenci kazanımlarında olmasına rağmen bu kitaplarda yeterince yer verilmediği belirtilmiştir. Ayrıca değerlerin dağılımının orantılı olması gerektiği vurgulanmıştır (Kuş, Merey ve Karatekin, 2013).

Geçmişte yapılan bazı araştırmalarla yapılan bu araştırma karşılaştırıldığında, değer aktarımı açısından 6 . sınıf İngilizce ders kitabının büyük oranda yeterli olduğu söylenebilir. Fakat ünitelerdeki konulara göre değerlerin dağılımının etkilendiği fark edilmiştir ve sorumluluk (23), sağllklı olmaya önem verme (22), demokrasiye önem verme (13), doğa sevgisi (13), müzikseverlik (12), okuma sevgisi (12), doğal çevreye karşı duyarlılı (11), farklllıklara saygl (11), hayvan sevgisi (11), israf etmeme (10), aile birliğine önem verme (9), aile birliğine önem verme (7), aile içi işbirliğine önem verme (7), sporseverlik (7), arkadaş sevgisi (5), milli değerlere önem verme (5) değerlerine daha s1k yer verilirken, eșitlik (2), aile sevgisi (1), çalışkanlık (1), tarihsel mirasa duyarlılık (1), estetik duyarlılık (1), paylaşma (1), nezaket (1), yardımseverlik(1), kardeş sevgisi (1) değerlerine ise çok az yer verilmiştir. Diğer taraftan belirlenen İngilizce öğretim programında (MEB, 2018) yer alan değerlerden adil olmaya önem verme, dürüstlük, sabır, vatanseverlik, öz denetim ve diğerkâmlığa ilişkin herhangi bir veriye rastlanmamıştır.

6. sınıf İngilizce ders kitaplarının incelenmesi neticesinde elde edilen sonuçlar 1şığında değer içeren materyallerin dengeli dağılımının daha fazla fayda sağlayacağı söylenebilir. Ayrıca İngilizce öğretim programında yer verilen fakat 6 . sınıf ders kitabında hiç yer verilmeyen ya da çok az yer verilen değerlere de yer verilmesinin daha uygun olacağı düşünülmektedir. Değer içeren materyallerin daha otantik ve ilgi çekici olması sağlanabilir. Bu sayede değer eğitimi diğer tüm derslerde olduğu gibi yabancı dil dersleriyle de bütünlük içinde yürütülebilir.

Bilgilendirme / Acknowledgement: Bu çalışmada, Halil İbrahim Aslan'ın, Ortaokul İngilizce Ders Kitaplarında Aktarılan Değerler, adlı yüksek lisans tezinin verilerinden faydalanılmıştır.

\section{KAYNAKÇA}

Altunışık, A., Coşkun, R., Bayraktaroğlu, S. \& Yıldırım, E. (2007). Sosyal Bilimlerde Araştırma Yöntemleri SPSS Uygulamalı. 5. Baskı. Sakarya: Sakarya Yayıncılık

Aydın, M. Z. (2008). Ailede Çocuğun Ahlak Eğitimi. 6. Baskı. Ankara: Nobel Yayın Dağıtım.

Aydın, M. Z. ve Akyol Gürler, Ş. (2014). Okulda Değerler Eğitimi. Ankara: Nobel Yayıncılık. 
Candan, D. \& Ergen, G. (2014). 3. Sınıf Hayat Bilgisi Ders Kitaplarının Temel Evrensel Değerleri İçermesi Bakımından İncelenmesi. Uşak Üniversitesi Sosyal Bilimler Dergisi, 7(1), 134-161.

Çekin, A. (2012). Değer Açısından İlköğretim Din Kültürü ve Ahlak Bilgisi Dersi Kazanımları: Bir İçerik Analizi. Din Bilimleri Akademik Araştırma Dergisi, 12 (2), 105-119.

Çengelci, T., Hancı, B. \& Karaduman, H. (2013). Okul Ortamında Değerler Eğitimi Konusunda Öğretmen ve Öğrenci Görüşleri. Değerler Eğitimi Dergisi, 11 (25), 33-56.

Demircan, F., Akıskalı, G., Berket, A. \& Günay, F. (2018). Ortaokul ve Imam Hatip Ortaokulları için Ingilizce 6 Ders Kitabı. 1. Bask1. Ankara: MEB Devlet Kitapları.

Demircioğlu, İ. \& Tokdemir, M. (2008). Değerlerin Oluşturulma Sürecinde Tarih Eğitimi: Amaç, İşlev ve İçerik. Değerler Ĕgitimi Dergisi, 6(15), 69-88.

Doğan, B. \& Gülüşen, A. (2011). Türkçe Ders Kitaplarındaki (6-8) Metinlerin Değerler Bakımından İncelenmesi. Sosyal Bilimler Dergisi, 1(2), 75-102.

Er, K, O. (2006). Yabancı Dil Öğretim Programlarında Kültürün Etkileri. Ankara Üniversitesi Eğitim Bilimleri Fakültesi Dergisi, 39(1), 1-14.

Eroğlu, E. \& Köktan, Y. (2008). Araştırma Metod ve Teknikleri (Ders Notları). 2. Baskı. Sakarya: Sakarya Yayıncilık.

Kaygana, M., Yapıcı, Ş. \& Aytan, T. (2013). Türkçe Ders Kitaplarında Değer Eğitimi. The Journal of Academic Social Science Studies (JASS), 6(7), 657-669.

Keskin, Y. (2008). Türkiye'de Sosyal Bilgiler Öğretim Programlarında Değerler Eğitimi: Tarihsel Gelişim, 1998 ve 2004 Programlarının Etkililiğinin Araştırılmast. Yayımlanmamış doktora tezi. Marmara Üniversitesi, Eğitim Bilimleri Enstitüsü, İstanbul.

Kuş, Z., Merey, Z. \& Karatekin, K. (2013). İlköğretim 4. ve 5. Sınıf Sosyal Bilgiler Ders Kitaplarında Yer Alan Değerler. Değerler Eğitimi Dergisi, 11(26), 183-214.

Lickona, T. (1991). Educating for Character: How our schools can teach respect and responsibity. New York: Bantham Books.

Milli Eğitim Bakanlı̆̆ (MEB). 2018. İngilizce Dersi Öğretim Programı. 9 Nisan 2019 tarihinde http://mufredat.meb.gov.tr/Dosyalar/201812411191321-\%C4\%B0NG\%C4 \%B0 L\% C4\%B0ZCE\%20\%C3\%96\%C4\%9ERET\%C4\%B0M\%20PROGRAMI\%20Klas\%C3\%B6rme b\%C3\%BC.pdf adresinden erişildi.

Milli Eğitim Bakanlı̆̆ı (MEB). 2019. Öğretim Programları. 20 Mart 2019 tarihinde http://mufredat.meb.gov.tr/ Programlar. Aspx adresinden erişildi.

Önder, S. (2018). Ortaokul 8. Sinıf Öğrencilerinin Sosyal Medyada Yansittıkları Değerler. Yayımlanmamış yüksek lisans tezi, Sakarya Üniversitesi Eğitim Bilimleri Enstitüsü, Sakarya.

Somuncu, S. (2008). Ilköğretim 7.Sinıf Türkçe Ders Kitabındaki Edebî Metinlerin Temel Evrensel Değerleri İçermesi Bakımından İncelenmesi. Yayımlanmamış yüksek lisans tezi, Afyon Kocatepe Üniversitesi Sosyal Bilimler Enstitüsü, Afyon.

Şimşek, N. (2013). Hayat Bilgisinde Kişisel Nitelik (Değer) Öğretimi. The Journal of Academic Social Science Studies (JASS), 6(1), 1325-1346.

Ünsal, Y. \& Güneş, B. (2002). Bir Kitap İnceleme Çalışması Örneği Olarak MEB İlköğretim 4. Sınıf Fen Bilgisi Ders Kitabına Fizik Konuları Yönünden Eleştirel Bir Bakış. Gazi Eğitim Fakültesi Dergisi, 22(3): 107-120

Yıldırım, A. \& Şimşek, H. (2011). Sosyal Bilimlerde Nitel Araştırma Yöntemleri. 6. Baskı. Ankara: Seçkin Yayıncılık. 